
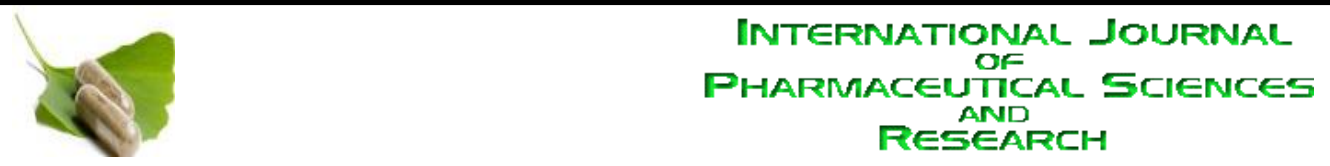

Received on 25 February, 2011; received in revised form 21 April, 2011; accepted 08 May, 2011

\title{
ANTIOXIDANT, ANALGESIC AND TOXIC POTENTIALITY OF METHANOLIC EXTRACT OF STEPHANIA JAPONICA (THUNB.) MIERS. LEAF
}

M. Habibur Rahman ${ }^{1}$, M. Badrul Alam ${ }^{2}$, M. Sarowar Hossain ${ }^{2}$, M. Kumar Jha ${ }^{1}$ and Anwarul Islam*1

Department of Pharmacy, Bangladesh University ${ }^{1}$, Dhaka, Bangladesh

Department of Pharmacy, Atish Dipankar University of Science \& Technology ${ }^{2}$, Dhaka, Bangladesh

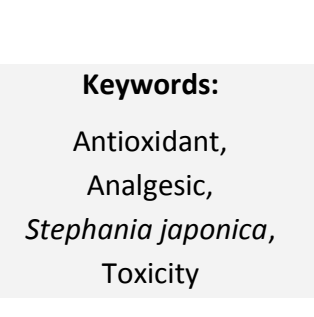

Correspondence to Author:

Dr. Anwarul Islam

Ph. D., Associate Professor, Department of Pharmacy, Bangladesh University, 15/1, Iqbal Road, Mohammadpur, Dhaka1207, Bangladesh

\section{ABSTRACT}

In the present study crude methanolic extract of Stephania japonica leaf was investigated for possible antioxidant, analgesic and cytotoxic activity. The extract showed antioxidant activity in DPPH radical scavenging activity, nitric oxide scavenging activity and reducing power assays. In both DPPH radical and NO scavenging assay, the extract exhibited moderate antioxidant activity and the $\mathrm{IC}_{50}$ values in DPPH radical scavenging and $\mathrm{NO}$ scavenging assays were found to be $105.55 \pm 1.06 \mu \mathrm{g} / \mathrm{ml}$ and $129.12 \pm 0.15 \mu \mathrm{g} / \mathrm{ml}$, respectively while the $\mathrm{IC}_{50}$ values of ascorbic acid were $12.30 \pm 0.11 \mu \mathrm{g} / \mathrm{ml}$ and $18.64 \pm 0.22 \mu \mathrm{g} / \mathrm{ml}$, respectively. Reducing power activity of the extract increased in a dose dependent manner. Analgesic activity of the crude extract was evaluated using acetic acid-induced writhing model of pain in mice. The crude extract at 200 $\mathrm{mg} / \mathrm{kg}$ and $400 \mathrm{mg} / \mathrm{kg}$ b.w. doses displayed significant $(p<0.001)$ reduction in acetic acid induced writhing in mice with a maximum effect of $75.89 \%$ reduction at $400 \mathrm{mg} / \mathrm{kg}$ b.w. which is comparable to the standard, diclofenac sodium (86.52 \%). The extract was also investigated for toxic potentiality using Brine Shrimp lethality bioassay. In this bioassay the extract showed significant toxicity to Brine Shrimp nauplii with the $\mathrm{LC}_{50}$ value of $25.19 \pm 0.98 \mu \mathrm{g} / \mathrm{ml}$.
INTRODUCTION: Free radicals contribute to more than one hundred disorders in humans including atherosclerosis, arthritis, ischemia and reperfusion injury of many tissues, central nervous system injury, gastritis, cancer and AIDS 1, 2. Aerobic cells are endowed with extensive antioxidant defense mechanisms including both low molecular weight scavengers, such as $\alpha$-tocopherol, cysteine, $\beta$ carotene, reduced glutathione, ascorbic acid and enzymatic systems, such as superoxide dismutase (SOD), catalase (CAT), glutathione peroxidase (GSHPx), glutathione reductase (GSH-Red) and glucose-6phosphate dehydrogenase (G6PD), which counteract the damaging effects of toxic oxygen species ${ }^{3}$. Currently, the possible toxicity of synthetic antioxidants has been criticized. It is generally assumed that frequent consumption of plant-derived phytochemicals from vegetables, fruit, tea, and herbs may contribute to shift the balance toward an adequate antioxidant status ${ }^{4}$. The interest in natural antioxidant, especially of plant origin, has greatly increased in recent years ${ }^{5}$. Thus recent studies have investigated the potential of plant products to serve as antioxidants to protect against various diseases induced by free radicals. Plant products including phenolics, flavonoids, tannins, proanthocyanidins, and various plant or herbal extracts have been reported to be radical scavengers and inhibitors of lipid peroxidation 6,7 . Pain is a sensorial modality and primarily protective in nature, but often causes discomfort. It is the most important symptom that brings the patient to physician. Analgesics relieve pain 
as a symptom, without affecting its cause ${ }^{8}$. Currently available analgesic drugs such as opiates and NSAIDs are not useful in all cases due to their adverse effects. In this respect new compounds with improved pain management capacity and fewer side effects are being sought with urgency.

\section{Stephania japonica (Thumb.) Miers, (Family-} Menispermaceae) is a slender twining shrub with greenish yellow flowers and large tubers. It is native to eastern and southern Asia and Australasia.

In Bangladesh, it is grown in many areas. The leaves and roots are bitter and astringent, and used in fevers, diarrhea, dyspepsia and urinary disease ${ }^{9}$.

As a part of our ongoing investigations on local medicinal plants of Bangladesh ${ }^{10}$, in this paper, we reported antioxidant, analgesic and toxic potentiality of the leaves of Stephania japonica.

\section{MATERIALS AND METHODS:}

Plant materials: The plant 'Stephania japonica (Thunb.) Miers was collected from the village Uthali under Jibannagar thana of Chuadanga district, Bangladesh during the month of August 2009. The plants were mounted on paper and the sample was identified by Mrs. Mahmuda Begum, senior scientific officer, Bangladesh National Herbarium, Dhaka, where the voucher specimen has been deposited. Its DACB Accession Number is 34, 393.

Chemicals: Sodium nitroprusside, were purchased from E. Merck (Germany). 1, 1-diphenyl-2-picrylhydrazyl (DPPH), sodium nitroprusside, ascorbic acid, quercetin, and potassium ferric cyanide were purchased from Sigma Chemical Co. Ltd, (St. Louis, MO, USA). Diclofenac-Na was collected from Square Pharmaceuticals Ltd., Bangladesh. All other chemicals and reagents were of analytical grade.

Preparation of plant extract: The plant material was shade-dried with occasional shifting and then powdered with a mechanical grinder, passing through sieve \#40, and stored in a tight container. The dried powder material $(1.5 \mathrm{~kg}$ ) was refluxed with $\mathrm{MeOH}$ for three hours. The total filtrate was concentrated to dryness, in vacuo at $40^{\circ} \mathrm{C}$ to render the $\mathrm{MeOH}$ extract for investigation.

Animal: For the experiment Swiss albino mice of either sex, 3-4 weeks of age, weighing between 20-25 g, were collected from the animal research branch of the International Center for Diarrheal Disease and Research, Bangladesh (ICDDRB). Animals were maintained under standard environmental conditions (temperature: $\left(24.0 \pm 1.0^{\circ}\right)$, relative humidity: $55-65 \%$ and $12 \mathrm{~h}$ light/12 $\mathrm{h}$ dark cycle) and had free access to feed and water ad libitum. The animals were acclimatized to laboratory condition for one week prior to experiments. All protocols for animal experiment were approved by the institutional animal ethical committee.

Phytochemical screening: The freshly prepared crude extract was qualitatively tested for the presence of chemical constituents. Phytochemical screening of the extract was performed using the following reagents and chemicals: Alkaloids with Dragendroff's reagent, flavonoids with the use of $\mathrm{Mg}$ and $\mathrm{HCl}$; tannins with ferric chloride and potassium dichromate solutions and saponins with ability to produce stable foam and steroids with Liebermann- Burchard reagent, reducing sugars with Benedict's reagent. These were identified by characteristic color changes using standard procedures $^{9}$.

\section{In vivo Analgesic screening:}

Acetic acid-induced writhing test: The analgesic activity of the samples was also studied using acetic acid-induced writhing model in mice. Test samples and vehicle were administered orally $30 \mathrm{~min}$ before intraperitoneal administration of $0.7 \%$ acetic acid but Diclofenac- $\mathrm{Na}$ was administered intraperitoneally 15 min before injection of acetic acid. After an interval of $5 \mathrm{~min}$, the mice were observed for specific contraction of body referred to as 'writhing' for the next $10 \mathrm{~min}^{11}$.

\section{In vitro Tests for antioxidant activity:}

Free radical scavenging activity measured by 1, 1diphenyl-2-picryl-hydrazyl (DPPH): The free radical scavenging activity of $\mathrm{MeOH}$ extract based on the scavenging activity of the stable 1,1-diphenyl-2picrylhydrazyl (DPPH) free radical, was determined by 
the method described by Braca et al. (2001) ${ }^{12}$. Plant extract $(0.1 \mathrm{ml})$ was added to $3 \mathrm{ml}$ of a $0.004 \% \mathrm{MeOH}$ solution of DPPH. Absorbance at $517 \mathrm{~nm}$ was determined after $30 \mathrm{~min}$, and the percentage inhibition activity was calculated from $\left[\left(A_{0}-A_{1}\right) / A_{0}\right] x$ 100 , where $A_{0}$ is the absorbance of the control, and $A_{1}$ is the absorbance of the extract/ standard. $I C_{50}$ value was calculated from the equation of line obtained by plotting a graph of concentration $(\mu \mathrm{g} / \mathrm{ml})$ versus $\%$ inhibition.

Nitric oxide radical scavenging assay: The procedure is based on the method, where sodium nitroprusside in aqueous solution at physiological $\mathrm{pH}$ spontaneously generates nitric oxide, which interacts with oxygen to produce nitrite ions that can be estimated using Greiss reagent. Scavengers of nitric oxide compete with oxygen leading to reduced production of nitrite ions. For the experiment, sodium nitroprusside $(10 \mathrm{mM})$ in phosphate buffered solution $(\mathrm{pH} 7.4)$ was mixed with different concentrations of plant extract of $S$. japonica dissolved in $10 \%$ DMSO and incubated at room temperature for $150 \mathrm{~min}$.

The same reaction mixture without the extract but the equivalent amount of the solvent used served as the control. After incubation, $0.5 \mathrm{ml}$ of Griess reagent (1\% sulfanilamide, $2 \% \quad \mathrm{H}_{3} \mathrm{PO}_{4}$ and $0.1 \% \quad \mathrm{~N}$-(1-naphthyl) ethylenediamine dihydrochloride was added. The absorbance was measured at $546 \mathrm{~nm}$ and the percentage inhibition activity was calculated from $\left[\left(A_{0}-A_{1}\right) / A_{0}\right] \times 100$, where $A_{0}$ is the absorbance of the control, and $A_{1}$ is the absorbance of the extract/ standard ${ }^{13}$. I $I_{50}$ value was calculated from the equation of line obtained by plotting a graph of concentration $(\mu \mathrm{g} / \mathrm{ml})$ versus $\%$ inhibition.

Reducing power activity: The reducing power of $S$. japonica was determined according to the method previously described ${ }^{14}$. Extracts at different concentrations in $1 \mathrm{ml}$ of $10 \%$ DMSO were mixed with TABLE 1: RESULT OF CHEMICAL GROUP TESTS OF THE METHANOL EXTRACT OF STEPHANIA JAPONICA LEAF

\begin{tabular}{cccccccc}
\hline Sample & Alkaloid & Steroid & Flavonoid & Reducing sugar & Tannin & Saponin & Glycoside \\
\hline ME of Stephania japonica & +++ & ++ & - & - & + & - \\
\end{tabular}

ME: Methanolic extract; (+): Present; $(-)$ : Absent; $(+++)$ : Reaction intensity is high; $(++)$ : Reaction intensity is medium; $(+)$ : Reaction intensity
$2.5 \mathrm{ml}$ of phosphatebuffer $(0.2 \mathrm{M}, \mathrm{pH} 6.6)$ and $2.5 \mathrm{ml}$ potassium ferricyanide $\left[\mathrm{K}_{3} \mathrm{Fe}(\mathrm{CN})_{6}\right](1 \%)$, and then the mixture was incubated at $50^{\circ} \mathrm{C}$ for $30 \mathrm{~min}$. Afterwards, mixture, which was then centrifuged at $3000 \mathrm{rpm}$ for $10 \mathrm{~min}$. Finally, $2.5 \mathrm{ml}$ of upper layer solution was mixed with $2.5 \mathrm{ml}$ distilled water and $0.5 \mathrm{ml} \mathrm{FeCl}_{3}$ $(0.1 \%)$, and the absorbance was measured at $700 \mathrm{~nm}$. Increased absorbance of the reaction mixture indicated increased reducing power.

Brine Shrimp Lethality Bioassay: The cytotoxic activity of the plant was evaluated using Brine Shrimp lethality bioassay method ${ }^{15}$ where 6 graded doses (viz,. $5 \mu \mathrm{g} / \mathrm{ml}, 10 \mu \mathrm{g} / \mathrm{ml}, 20 \mu \mathrm{g} / \mathrm{ml}, 50 \mu \mathrm{g} / \mathrm{ml}, 100 \mu \mathrm{g} / \mathrm{ml}$, $200 \mu \mathrm{g} / \mathrm{ml}$ ) were used. Brine shrimps (Artemia salina Leach) nauplii Ocean 90, USA were used as test organisms. For hatching, eggs were kept in brine with a constant oxygen supply for 48 hours. The nature nauplii were then used in the experiment. DMSO was used as a solvent and also as a negative control. The median lethal concentration $\mathrm{LC}_{50}$ of the test sample after 24 hours was obtained by a plot of percentage of the dead shrimps against the logarithm of the sample concentration. Vincristine sulfate was used as a reference standard in this case.

Statistical analysis: All the in vitro experimental results were mean \pm SEM of three parallel measurements. Results of in vivo study were given as mean \pm S.E.M. and data were evaluated by using student's t test. $P$ values $<0.001$ were regarded as significant.

\section{RESULTS:}

Phytochemical screening: Phytochemical analyses of the crude extract revealed the presence of steroid, alkaloid, tannin, and glycoside (Table 1). $2.5 \mathrm{ml}$ of trichloroacetic acid (10\%) was added to the 


\section{In vivo Analgesic screening:}

Acetic acid-induced writhing test: Table 2 shows the effects of the extract of on acetic acid-induced writhing in mice. The oral administration of both doses of $S$. japonica extract significantly $(p<0.001)$ inhibited writhing response induced by acetic acid in a dose dependent manner.

Table 2: Effects of the methanolic extract of Stephania japonica leaf on acetic acid-induced writhing in mice

\begin{tabular}{cccc}
\hline Groups & Dose $(\mathrm{mg} / \mathrm{kg})$ & No. of writhing & $\begin{array}{c}\text { Percentage of } \\
\text { protection }\end{array}$ \\
\hline Group - I & Vehicle & $28.2 \pm 0.748$ & - \\
Group - II & 10 & $3.8 \pm 1.008^{* *}$ & 86.52 \\
Group - III & 200 & $11.8 \pm 0.765^{* *}$ & 58.16 \\
Group - IV & 400 & $6.8 \pm 0.637^{* *}$ & 75.89 \\
\hline
\end{tabular}

Values are mean \pm SEM, $(n=5) ;{ }^{* *} p<0.001$, Student's t test as compared to vehicle control.

Group-I animals received vehicle (1\% Tween 80 in water), Group-II received Diclofenac-Na $10 \mathrm{mg} / \mathrm{kg}$ body weight, Group-III and Group-IV were treated with 200 and $400 \mathrm{mg} / \mathrm{kg}$ body weight (p.o.) of the crude extract of $S$. japonica leaf

\section{In vitro Antioxidant activity:}

DPPH radical scavenging activity: The percentage (\%) scavenging of DPPH radical was found to be concentration dependent i.e. concentration of the extract between $10-200 \mu \mathrm{g} / \mathrm{ml}$ greatly increasing the inhibition activity. The $\mathrm{IC}_{50}$ value of the extract was $105.55 \pm 1.06 \mu \mathrm{g} / \mathrm{ml}$, as opposed to that of ascorbic acid $\left(\mathrm{IC}_{50} 12.30 \pm 0.11 \mu \mathrm{g} / \mathrm{ml}\right)$, which is a well known antioxidant.

Nitric oxide (NO) scavenging activity: Table 3 shows the result of nitric oxide scavenging activity ( $I C_{50}$ value) of the methanolic extract of $S$. japonica compared with various reference compounds such as ascorbic acid and quercetin. $I C_{50}$ value of the extract of was $129.12 \pm 0.15 \mu \mathrm{g} / \mathrm{ml}$, whereas, standard ascorbic acid and quercetin showed $18.64 \pm 0.22 \mu \mathrm{g} / \mathrm{ml}$ and $27.69 \pm 0.57 \mu \mathrm{g} / \mathrm{ml}$ respectively.
TABLE 3: ANTIOXIDANT ACTIVITIES OF THE S. JAPONICA LEAF EXTRACT ON DPPH, AND NO

\begin{tabular}{ccc}
\hline Sample & $\begin{array}{c}{ }^{\mathrm{a}} \mathrm{DPPH} \\
\mathrm{IC}_{50}(\mu \mathrm{g} / \mathrm{ml})\end{array}$ & $\begin{array}{c}{ }^{\mathrm{b}} \mathrm{NO} \\
\mathrm{IC}_{50}(\mu \mathrm{g} / \mathrm{ml})\end{array}$ \\
\hline $\begin{array}{c}\text { Methanolic extract of } S . \\
\text { japonica }\end{array}$ & $105.55 \pm 1.06^{*}$ & $129.12 \pm 0.15^{*}$ \\
Ascorbic acid & $12.30 \pm 0.11$ & $18.64 \pm 0.22$ \\
Quercetin & & $27.69 \pm 0.57$ \\
\hline
\end{tabular}

${ }^{a} \mathrm{DPPH}$ is the free radical scavenging activity $\left(\mathrm{IC}_{50}: \mu \mathrm{g} / \mathrm{ml}\right),{ }^{b} \mathrm{NO}$ is the inhibition of NO production $\left(\mathrm{IC}_{50}: \mu \mathrm{g} / \mathrm{ml}\right),{ }^{*} p<0.001$ by student's test for values between the sample and the control

Reducing power ability: For the measurement of the reductive ability, we investigated the $\mathrm{Fe}^{3+}$ to $\mathrm{Fe}^{2+}$ transformation in the presence of methanolic extract. Like the antioxidant activity, the reducing power of $S$. japonica increased with increasing concentration of the sample. Figure 1 shows the reductive capabilities of the S. japonica compared with ascorbic acid, galic acid and quercetin.

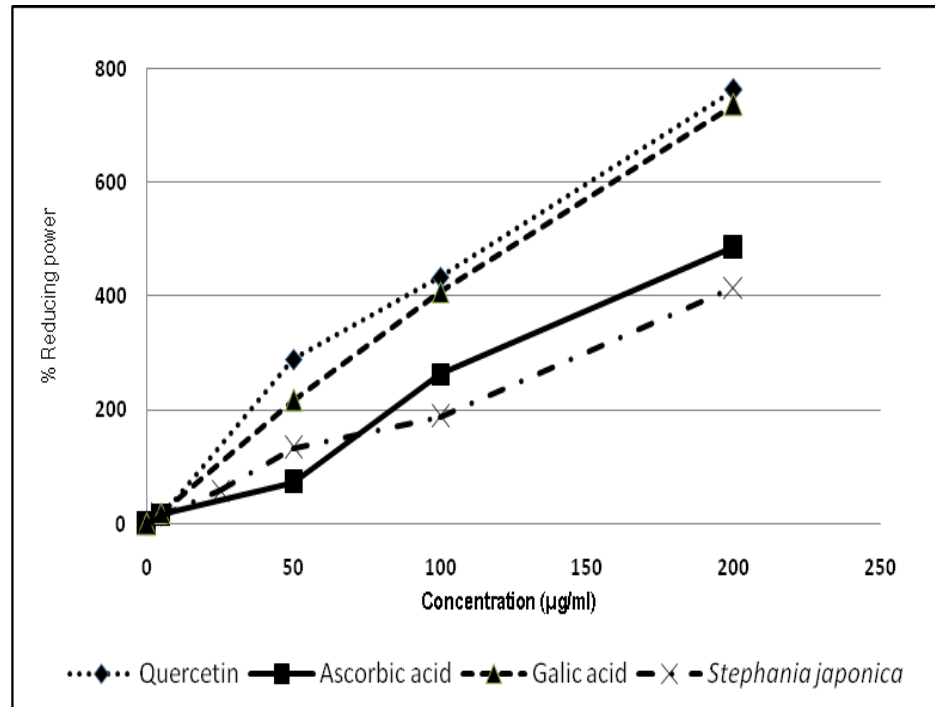

FIG. 1: REDUCING POWER OF METHANOLIC EXTRACT OF $S$. JAPONICA, ASCORBIC ACID, GALIC ACID AND QUERCETIN BY SPECTROPHOTOMETRIC DETECTION OF $\mathrm{Fe}^{3+}$ TO $\mathrm{Fe}^{2+}$ TRANSFORMATION

Results are mean \pm SEM of three parallel measurements

Brine Shrimp lethality bioassay: The result of Brine Shrimp lethality bioassay is given in Table 4. S. japonica leaf extract displayed strong toxic potentiality. $\mathrm{LC}_{50}$ value for the extract was found to be $25.19 \pm 0.98$ $\mu \mathrm{g} / \mathrm{ml}$. 
TABLE 4: BRINE SHRIMP LETHALITY BIOASSAY OF CRUDE METHANOL EXTRACT OF STEPHANIA JAPONICA LEAF

\begin{tabular}{|c|c|c|c|c|c|c|}
\hline Test sample & $\begin{array}{l}\text { Concentration } \\
(\mu \mathrm{g} / \mathrm{ml})\end{array}$ & Log Conc. & $\begin{array}{l}\text { No. of dead shrimps } \\
\text { (out of 10) }\end{array}$ & $\begin{array}{c}\% \\
\text { Mortality }\end{array}$ & $\begin{array}{c}\mathrm{LC}_{50} \text { of test sample } \\
(\mu \mathrm{g} / \mathrm{ml})\end{array}$ & $\begin{array}{l}\mathrm{LC}_{50} \text { of Vincristine sulphate } \\
\qquad(\mu \mathrm{g} / \mathrm{ml})\end{array}$ \\
\hline \multirow{7}{*}{$\begin{array}{c}\text { Methanolic extract of } S \text {. } \\
\text { japonica }\end{array}$} & 200 & 2.303 & 10 & 100 & \multirow{7}{*}{$25.19 \pm 0.98$} & \multirow{7}{*}{$0.25 \pm 0.22$} \\
\hline & 200 & 2.303 & 10 & 100 & & \\
\hline & 160 & 2.204 & 10 & 100 & & \\
\hline & 80 & 1.903 & 9 & 90 & & \\
\hline & 40 & 1.602 & 7 & 70 & & \\
\hline & 20 & 1.301 & 4 & 40 & & \\
\hline & 10 & 1.000 & 2 & 20 & & \\
\hline
\end{tabular}

DISCUSSION:The oral administration of both doses of S. japonica extract significantly $(p<0.001)$ inhibited writhing response induced by acetic acid in a dose dependent manner. Acetic acid-induced writhing model represents pain sensation by triggering localized inflammatory response. Such pain stimulus leads to the release of free arachidonic acid from tissue phospholipids ${ }^{16}$. The acetic acid induced writhing response is a sensitive procedure to evaluate peripherally acting analgesics The response is thought to be mediated by peritoneal mast cells ${ }^{17}$, acid sensing ion channels ${ }^{18}$ and the prostaglandin pathways ${ }^{19}$.

Preliminary phytochemical screening showed the presence of tanin, alkaloid and glycoside in the plant extract. So, the observed analgesic activity may be attributed to these compounds. Moreover, recent studies suggest that the inflammatory tissue damage is due to the liberation of reactive oxygen species form phagocytes invading the inflammation sites ${ }^{20}$. Again the plant extracts demonstrated antioxidant action in the tested models. So it can be assumed that Cyclooxygenase (COX) inhibitory activity together with antioxidant activity may reduce the production of free arachidonic acid from phospholipid or may inhibit the enzyme system responsible for the synthesis of prostaglandins and ultimately relive pain-sensation.

Polyphenolic compounds, like flavonoids, tannins and phenolic acids, commonly found in plants have been reported to have multiple biological effects, including antioxidant activity $21,22,23,24$. Tannic acid present in the plant extract, as evident from phytochemical screening, may be responsible for the antioxidant action. NO scavenging capacity of the extract may help to arrest the chain of reactions initiated by excess generation of NO that are detrimental to the human health. Nitric oxide is also implicated for inflammation, cancer and other pathological conditions ${ }^{25}$. A direct correlation between antioxidant capacity and reducing power of certain plant extracts has been reported ${ }^{26}$. The reducing properties are generally associated with the presence of reducing agents which have been shown to exert antioxidant action by breaking the free radical chain by donating a hydrogen atom 27 . Therefore, antioxidants with free radical scavenging activities may have great relevance in the prevention and treatment of diseases associated with oxidants or free radicals ${ }^{28}$.

The extract also showed significant cytotoxicity on Brine Shrimp nauplii. This may be due to the fact that $S$. japonica contains isotrilobine and trilobine, bisbenzylisoquinoline alkaloids, which was previously reported to possess multidrug-resistance-reversing activity in human breast cancer cell line ${ }^{29}$.

CONCLUSION: The study clearly indicates that the extract possesses antioxidant and cytotoxic substances. At the same time its ability to suppress abdominal writhes confirms the analgesic property of the extract. These findings justify the traditional uses of this plant in the treatment of diabetes, wounds, inflammatory conditions, worms, infestations and malarial fever. Further research is necessary for elucidating the active principles.

ACKNOWLEDGEMENT: The authors would like to thank the Department of Pharmacy, Jahangirnagar University for providing plants and laboratory facilities and also to the Department of Pharmacy, Bangladesh University for providing lab facilities for the research work. 


\section{REFERENCES:}

1. Kumpulainen JT, Salonen JT: Natural Antioxidants and Anticarcinogens in Nutrition, Health and Disease, The Royal Society of Chemistry, UK 1999; pp 178-187.

2. Cook NC, Samman S: Flavonoids- chemistry, metabolism, cardioprotective effects, and dietary sources. Nutritional Biochemistry 1996; 7: 66- 76.

3. Halliwell B, Gutteridge JMC: Free Radicals in Biology and Medicine. Clarendon Press: Oxford 1989; 2nd edn.

4. Halliwell B, Aeschbach R, Löliger J, Aruoma OI: The characterization of antioxidants. Food Chem. Toxicol. 1995; 33: 601-617.

5. Jayaprakasha GK, Jaganmohan Rao: Phenolic constituents from lichen Parmontrema stuppeum. Hale and antioxidant activity. Zeitschrift Für Naturforscung. 2002; 55: 1018-1022.

6. Xie B, Shi H, Chen Q, Ho CT: Antioxidant properties of fractions and polyphenol constituents from green, long and black teas. Life Sci. 1993; 17: 77-84.

7. Formica JV, Regelson W: Review of the biology of quercetin and related bioflavonoids. Food Chem Toxicol. 1995; 33: 1061-1080.

8. Tripathi KD: Essentials of Medical Pharmacology. Jaypee Brothers Medical Publishers (P) Ltd. New Delhi, India 1999; 4th Ed. pp. 432.

9. Ghani A: Medicinal Plants of Bangladesh. The Asiatic Society of Bangladesh, 2003; 2nd Revised Edn. Dhaka, Bangladesh.

10. Mazumder $\mathrm{MEH}$, Alam MB, Alam MA, Jamila M, Muhsin MDA: Investigation of secondary metabolites, antioxidant and cytotoxic activities of the leaf extract of Portulaca oleracea Linn. Bangladesh J life Sci, 2009; 21 (1): 17-22.

11. Ahmed F, Selim MST, Das AK, Choudhuri MSK: Antiinflammatory and antinociceptive activities of Lippia nodiflora Linn. Pharmazie 2004; 59: 329-333.

12. Braca A, Tommasi ND, Bari LD, Pizza C, Politi M, Morelli I: Antioxidant principles from Bauhinia terapotensis. J Nat Prod. 2001; 64: 892-895.

13. Sreejayan N, Rao MNA. Nitric oxide scavenging by curcuminoids. J Pharm Pharmacol. 1997; 49: 105-107.

14. Oyaizu M: Studies on product of browning reaction prepared from glucose amine. Japanese J Nutrition 1986; 44: 307-315.

15. Mayer BN, Ferrigni NR, Potnam JE, Jacobson LB, Nicholas DE, Mclaughin JL: Brine Shrimp: A convenient bioassay for active plant constituents. Planta Medica 1982; 45: 31-34.

16. Ahmed F, Hossain MH, Rahman AA, Shahid IZ: Antinociceptive and sedative effects of the bark of Cerbera odollam Gaertn. Orien Pharm Exp. Med. 2006; 6(4): 344-348.
17. Ronaldo AR, Mariana LV, Sara MT, Adriana BPP, Steve P, Ferreira SH, Fernando QC: Involvement of resident macrophages and mast cells in the writhing nociceptive response induced by zymosan and acetic acid in mice. Eur $J$ Pharmacol., 2000; 387: 111-118.

18. Voilley N: Acid-Sensing Ion Channels (ASICs): New Targets for the Analgesic effects of Non-Steroid Anti-Inflammatory Drugs (NSAIDs). Current Drug Targets-Inflammation \& Allergy, 2004; 3: 71-79.

19. Vogel HG, Vogel WH: Pharmacological Assays. In: Drug Discovery and Evaluation. Springer Verlag, Germany, 1997; Chapter H: pp. 368-370.

20. Parke DV, Sapota A: Chemical toxicity and reactive species. Int. J. Occup. Med. Environ. Health, 1996; 9: 119-123.

21. Brown JE, Rice-Evans CA: Luteolinrich artichoke extract protects low density lipoprotein from oxidation in vitro. Free Rad. Res., 1998; 29: 247-255.

22. Vinson JA, Dabbagh YA, Serry MM, Jang J: Plant flavonoids, especially tea flavonols are powerful antioxidants using an in vitro oxidation model for heart disease. J. Agric. Food Chem., 1995; 43: 2800-2802.

23. Gil MI, Ferreres F, Tomás-Barberán FA: Effect of postharvest storage and processing on the antioxidant constituents (flavonoids and vitamin C) of fresh-cut spinach. J. Agric. Food Chem., 1999; 47: 2213-2217.

24. Kähkönen MP, Hopia Al, Vuorela HJ, Rauha JP, Pihlaja K, Kujala TS, Heinonen M: Antioxidant activity of plant extracts containing phenolic compounds. J. Agric. Food Chem., 1999; 47: 3954-3962.

25. Moncada A, Palmer RMJ, Higgs EA: Nitric oxide: Physiology, pathophysiology and pharmacology. Pharmacol. Rev., 1991; 43: 109-142.

26. Tanaka M, Kuie CW, Nagashima Y, Taguchi T: Applications of antioxidative Maillard reaction products from histidine and glucose to sardine products. Nippon Suisan Gakkaishi, 1988; 54: 1409-1414.

27. Duh PD, Tu YY, Yen GC: Antioxidant activity of the aqueous extract of harng Jyur (Chrysanthemum morifolium Ramat). Lebensmittel- Wissenschaft and Technol., 1999; 32: 269-277.

28. Soares JR, Dinis TCP, Cunha AP, Almeida LM: Antioxidant activities of some extracts of thymus zygis. Free Rad. Res., 1997; 26: 469-478.

29. Andrea M, Hall, Chang CJ: Multidrug-Resistance Modulators from Stephania japonica, J. Nat. Prod., 1997; 60 (11): 11931195. 